\title{
On the taphonomy of the late Maastrichtian (Late Cretaceous) marine turtle Allopleuron hofmanni ${ }^{\star}$
}

\section{R. Janssen ${ }^{1,}{ }^{*}$, R.R. van Baal ${ }^{1} \&$ A.S. Schulp ${ }^{2}$}

1 Faculteit der Aard- en Levenswetenschappen, Vrije Universiteit Amsterdam, De Boelelaan 1085, NL-1081 HV Amsterdam, the Netherlands.

2 Natuurhistorisch Museum Maastricht, de Bosquetplein 6-7, NL-6211 KJ Maastricht, the Netherlands.

* Corresponding author. Email: rjn600@falw.vu.nl.

Manuscript received: March 2011, accepted: July 2011

\begin{abstract}
An exhaustive screening of public collections containing remains of the latest Cretaceous (late Maastrichtian) marine turtle Allopleuron hofmanni (Gray, 1831) from the type area of the Maastrichtian Stage (southeast Netherlands, northeast Belgium) shows the available material to represent almost exclusively adult individuals. The various skeletal elements are not preserved in proportionally equal abundance, with portions of carapace, pectoral girdle, cranium and mandible overrepresented. These observations can be explained by population characteristics and taphonomic factors. During the late Maastrichtian, while hatchlings and juveniles in all likelihood lived and fed elsewhere, extensive seagrass meadows might have supported a population of only adult marine turtles.
\end{abstract}

Keywords: Allopleuron hofmanni, Cretaceous, Maastrichtian, marine turtles, population characteristics, taphonomy

\section{Introduction}

Pioneer vertebrate palaeontologist Petrus Camper was the first to describe the large-sized marine turtles from the type Maastrichtian, referring to them as a 'large turtle' (Camper, 1786). An apt term, because Allopleuron hofmanni attains average carapace lengths of $1.4 \mathrm{~m}$, this being comparable to the modernday leatherback, Dermochelys coriacea. The generic name, derived from the Greek, translates as 'different pleurals', because the costals (formerly referred to as pleurals) are highly reduced in this species. The specific epithet was given by Gray (1831) in honour of the renowned fossil collector Jean-Leonard Hoffmann. The rules of Zoological Nomenclature require Gray's misspelling, 'hofmanni' with a single ' $\mathrm{f}$ ', to be maintained.

The fact that marine turtles are usually restricted to the tropical realm did not escape Ubaghs's (1883) attention, which resulted in an early palaeoclimatological interpretation of the type Maastrichtian seas using vertebrate fossils. He observed (p. 25), '... une certaine analogie des mers tropicales avec celle à laquelle nous devons la formation de la craie supérieure de
Maestricht, analogie que j'ai trouvée dans la richesse de celle-ci en restes fossiles de tortues marines, si fréquentes dans les mers tropicales.' In spite of having presumably limited material available for study, Ubaghs added a few poignant remarks (p. 25) on the preservation of the material, the scarcity of articulated material being particularly striking, 'Malgré le grand nombre d'ossements isolés qu'on trouve disséminés partout dans notre dépôt, il est extrêmement rare qu'on y rencontre un squelette entier ou tant soit peu complet.' Ubaghs explained (p. 25) this pattern by wave and current action; for articulated material to be preserved, '... il aurait fallu que l'animal, immédiatement après sa mort, eût été entièrement enseveli dans la vase; mais comme le plus souvent il n'en a pas été ainsi, les extrémités les plus exposées, librement articulées en non protégées par la carapace, ont été décomposées en enlevées.'

Well over a century later, skeletal remains of $A$. hofmanni are still exclusively recovered from a relatively small geographic area and from a limited stratigraphic range: the Maastrichtian type area in southern Limburg (the Netherlands) and adjacent provinces of Limburg and Liège in northeast Belgium. During the

* In: Jagt, J.W.M., Jagt-Yazykova, E.A. \& Schins, W.J.H. (eds): A tribute to the late Felder brothers - pioneers of Limburg geology and prehistoric archaeology. 
Late Cretaceous this area was covered by a shallow subtropical sea (Jagt, 1999; Herngreen \& Wong, 2007), all material of $A$. hofmanni being preserved in rather coarse-grained biocalcarenitic limestones laid down here.

The most comprehensive study of A. hofmanni to date is that by Mulder (2003), who investigated some thirty specimens, all of them representing adult individuals. Younger growth stages of $A$. hofmanni are conspicuously absent. This suggests that there is a marked preservation bias against smaller, and thus younger, individuals, an extreme collecting bias skewed to larger individuals, the absence of young individuals as inhabitants of this area, or a combination of these factors. The correct interpretation of any one of these scenarios has significant implications for the reconstruction of this taxon's palaeobiology and palaeoecology. For the present note, we have studied the relative size distribution and the presence or absence of skeletal elements in order to gain a better understanding of the absence of juvenile individuals in collections.

\section{Material and methods}

We compiled a detailed and exhaustive overview of material of Allopleuron hofmanni housed in the collections of the following public institutions: Natuurhistorisch Museum Maastricht (NHMM; Maastricht, the Netherlands), Teylers Museum (TM; Haarlem, the Netherlands), Nederlands Centrum voor Biodiversiteit (Naturalis; NCB-RGM; Leiden, the Netherlands), Natuurhistorisch Universitair Museum Utrecht (NHUMU; Utrecht, the Netherlands), Geologisch Museum Hofland (Laren, the Netherlands), Natuurmuseum Brabant (NMB; Tilburg, the Netherlands), Institut royal des Sciences naturelles de Belgique (IRScNB; Brussels, Belgium), The Natural History Museum (NHM; London, England), Muséum national d'Histoire naturelle (MNHN; Paris, France), Museum für Naturkunde (MFN; Berlin, Germany) and Yale Peabody Museum (YPM; New Haven, Connecticut, USA).

Most specimens in museum collections are composed of only one or a handful skeletal elements that are frequently broken. Larger, articulated specimens, comprising more than a few elements, are rare, and most of those consist of co-ossified carapace elements. Because a large proportion of the material comes from older collections, provenance data associated with the specimens generally are very limited. Labels rarely supply more than the name of the quarry or that of the general region where the specimen was found. This precludes the inclusion of a more detailed stratigraphic level and/or sedimentological context into the analysis.

We have personally reviewed, identified and measured all specimens, except for the A. hofmanni material in the collections at Paris, New Haven and Berlin. Data on specimens in these collections were compiled from published accounts and correspondence with the curators in charge. Based on these data, the relative abundance of the skeletal elements and the total size of the animals (at the time of death) were calculated. For practical purposes a linear allometric ontogenetic relationship was assumed, with the most complete (albeit not the largest) adult skeleton, NHMM 000001 considered to constitute a '100 per cent' baseline. These data enabled us to evaluate the size distribution of Allopleuron fossils from the Maastrichtian type area.

\section{Taphonomy}

Due to the often limited provenance data and precise stratigraphic/sedimentological context, realistically available taphonomic data are limited to analysis of bone surface modification, presence or absence of skeletal elements, and bone size distributions. The specimens studied show a general lack of abrasional features other than tooth marks. Most finds consist of single skeletal elements or several articulated ones, whereas more complete skeletons are rare, an observation consistent with that of Ubaghs (1883). The general absence of abrasional features may be the result of limited post-mortem transportation and a relatively quiet setting at final burial. However, Brand et al. $(2000,2003)$ indicated that, after death, turtles in subaqueous environments can undergo significant transport because of bloating and consequential floating, which does not produce any form of abrasion on bones.

Teeth marks generally consist of small scrapes, shallow and closely spaced, which we attribute to scavengers rather than predators. These marks are found only on the outer surfaces of carapace elements. Scavenging, for instance by sharks of the genus Squalicorax, has been reported previously from the Maastrichtian type area (Dortangs et al., 2002). These observations might indicate that $A$. hofmanni was not a regular prey for predators.

The normalised frequency of the various skeletal elements of $A$. hofmanni as represented in museum collections is shown in Fig. 1; it allows the observation that these are not preserved in proportionally equal abundance. The commonest elements are (portions of) the skull, lower jaw, pectoral girdle and carapace. of the carapace elements, the nuchal is particularly common. Two factors can be considered here. First of all, the commonest elements are sturdy and robust, built to withstand substantial force. This holds true especially for the carapace elements and the skull. The pectoral girdle also is of sturdy build, because most of the propulsive musculature is attached to it (Wyneken, 2001). Secondly, the commonest skeletal elements are all of relatively large size. Large-sized elements can only be processed by large scavengers, thus making it more likely that these are preserved. The opposite is true for small bones and elements belonging to the appendicular skeleton. The smaller elements of tail and limbs are easily accessible meals for predators and scavengers alike. Small bones and bones not connected by ossification or tough ligaments have a lower preservation potential, because they are more prone to 

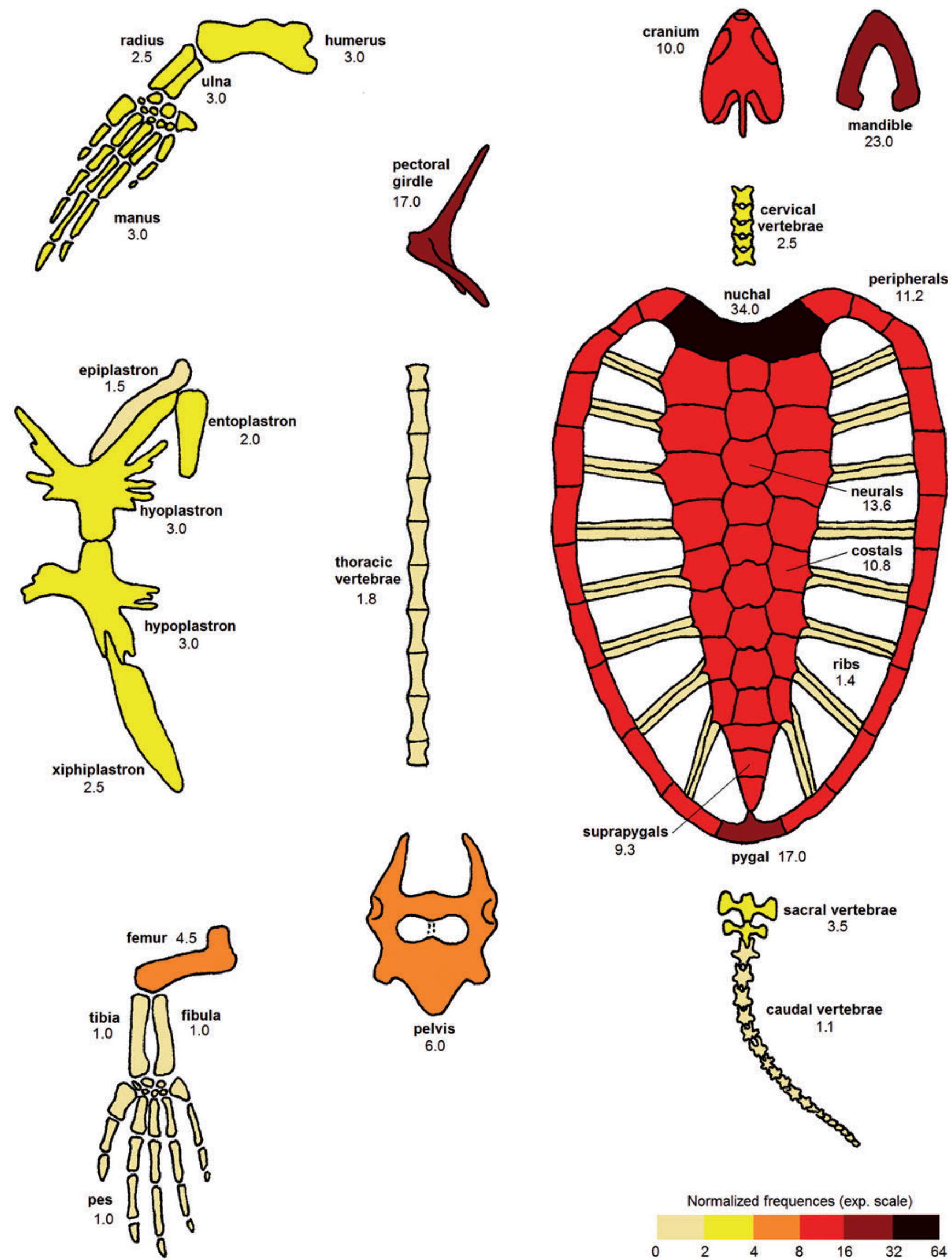

1.1
caudal
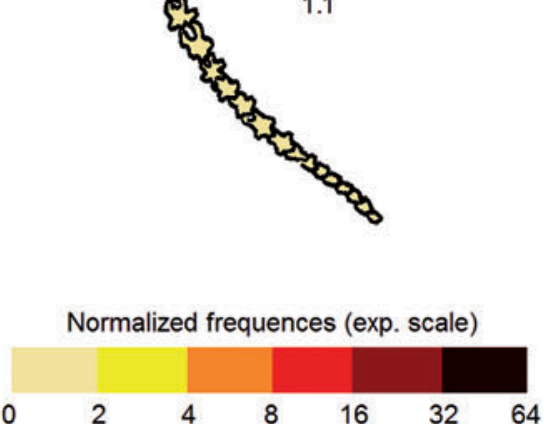

Fig. 1. 'Exploded view' of the skeleton of Allopleuron hofmanni with colour-coded abundances, corrected for the relative number of bone elements in the animal's skeleton. 
disarticulation by predator activity or scatter by current action (as noted already by Ubaghs, 1883). Of note is the fact that carapace elements are found relatively often in articulation. Where carapace elements are found disarticulated, fractures do not necessarily follow the sutures. Therefore, we assume that the sutures are not consistently the weakest structural links in the chain. It is interesting to compare these observations to the work by Meyer (1991) on the decomposition of the carapace of the present-day hawksbill turtle, Eretmochelys imbricata; buried in a lagoonal setting the carapace will completely disarticulate within ten days. Differences in size and composition of the carapace as well as the very different burial context (first bloat and float, then deposition) may well explain the different observations.

A collecting bias is certainly involved as well. Larger bones are more easily spotted and collected. Material in early collections was often acquired by private collectors from quarrymen, and larger (i.e., more spectacular) fossils were most sought after. Smaller elements, such as vertebrae, are more difficult to prepare and more easily damaged and perhaps therefore underrepresented in the current collections too.

In Fig. 1, the factors outlined above are reflected by the small numbers of elements of the appendicular skeleton as well as thoracic, caudal and cervical vertebrae. An interesting result is the relative paucity of plastron elements. Like the carapace, plastron bones are relatively large and built for strength; despite this trait, they are remarkably rare. This might be because they are not fused like carapace elements and their long, finger-like processes appear prone to fracturing beyond recognition. We also expect that predators or scavengers gained access to the turtle's internal organs via its ventral side, thereby possibly breaking up and scattering plastron elements.

\section{The type Maastrichtian Allopleuron hofmanni population}

Although ectothermic vertebrates usually do not display strictly deterministic growth curves (Halliday \& Verrell, 1988), correlations between body size and age in extant sea turtles appear reliable enough for rough age estimates (e.g., Chaloupka \& Zug, 1997 for Lepidochelys kempii; Zug et al., 2002 for Chelonia mydas) and certainly for determining if a certain individual was a hatchling, juvenile or adult. We would expect a population of A. hofmanni to encompass body sizes ranging from less than 10 centimetres to more than 1.5 metres. To see how this translates into the fossil record as recovered from the type Maastrichtian, we estimated the carapace length of the individuals (wherever possible) by using dimensions of the numerous partial specimens (Fig. 2), and conclude that this range of body sizes is not present at all in specimens of $A$. hofmanni. The majority have a carapace length in excess of one metre (Fig. 2). We are confident in ascribing 99 per cent of all specimens to the late juvenile stage and adult age classes (see Supplementary material).

As discussed above, taphonomic processes exert a bias towards large fossil remains, some very obvious: young turtles can be swallowed whole by predators, adult turtles cannot. Old turtles can die of old age, juveniles not. And large fossils are more sought after by collectors. These factors all provide a partial explanation for the observed population characteristics. Yet, the same processes have an impact on all vertebrates, failing to produce a bias as strong as the one we have observed. It is statistically very unlikely for these biases to explain away the 99 per cent representation of subadult and older. Many other marine reptile taxa such as mosasaurs are represented by a much wider size range in the type Maastrichtian (e.g. Kuypers

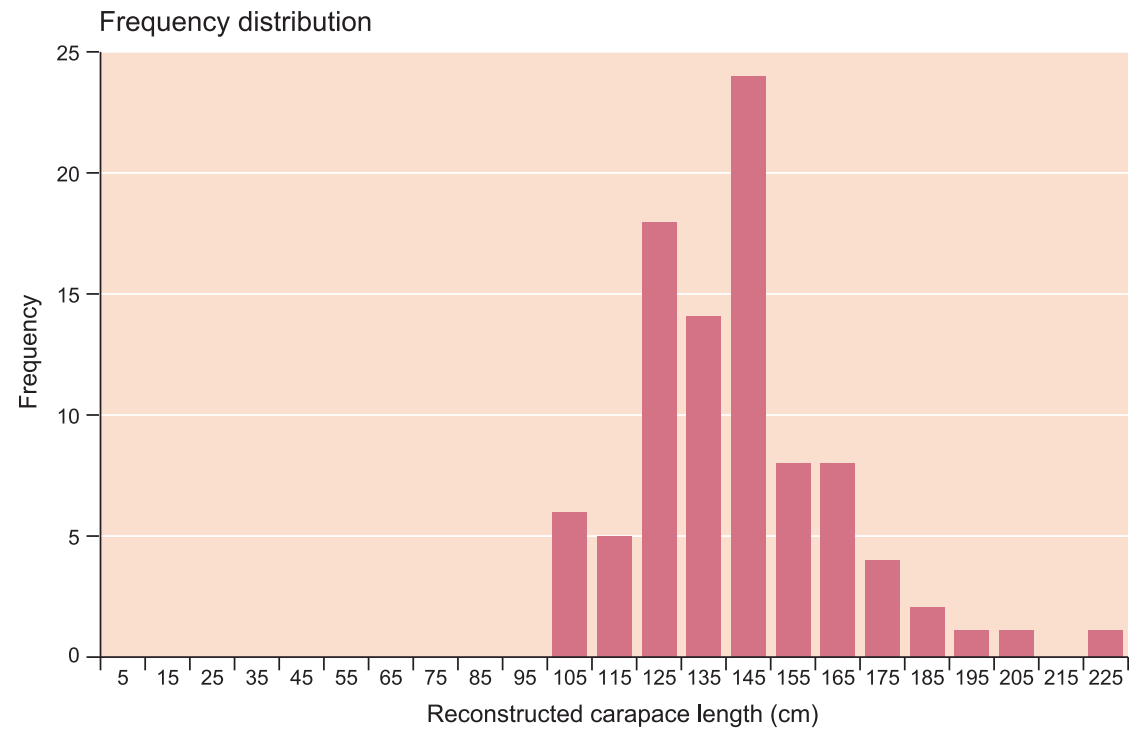

Fig. 2. Frequency distribution of carapace lengths of specimens of Allopleuron hofmanni. In most cases, no complete carapace was present, and carapace lengths were estimated using specimen NHMM 000001 as a reference. A total of 92 specimens were used to construct this graph; other specimens were excluded because of uncertain identification of the skeletal element involved or incomplete preservation. Due to intraspecific variation between the relative size of particular skeletal elements and total body size, this figure primarily provides an indication of the general range of carapace lengths (all $>90 \mathrm{~cm}$ ), and should not be interpreted as a precise record of the original carapace lengths. 
et al., 1998). Therefore we propose that, in addition to the taphonomic factors outlined above, the regional population composition is also a major factor. The stratigraphic and spatial distribution of $A$. hofmanni coincides remarkably well with that of the seagrass species Thalassotaenia debeyi (Van der Ham et al., 2007). It is not unthinkable that the seagrass meadows were the primary food source and provided a habitat during the adult life stage. If the population was composed solely of adult individuals, this would suggest that $A$. hofmanni moved through different, specific habitats during the various ontogenetic stages. This development can be compared with the life cycle of the extant green turtle, Chelonia mydas, which displays dramatic changes in lifestyle and habitat when reaching the adult stage. Like other contemporary marine turtles, green turtle hatchlings and juveniles hide in floating seaweed patches in the open ocean, feeding on shrimp, fish and jellyfish, in what are termed 'the lost years' (sensu Perrine, 2003). After this phase, the turtles move inshore and change their diet (Reich et al., 2007). At this stage in life, the green turtle develops into a herbivorous bottom-dwelling adult (Lutz et al., 2003). Hypothetically, a similar life cycle development may have been responsible for geographic separation of individuals of $A$. hofmanni of different ages.

\section{Conclusions}

The fossil record of Allopleuron hofmanni is composed almost entirely of remains of adult specimens. This may be explained by the assumption that the population consisted almost exclusively of adult individuals in this particular habitat, and by taphonomic processes which introduced a bias towards large, strong and robust skeletal elements. We can hypothesise that adult individuals inhabited the coastal, shallow environment of the Maastrichtian type area, while hatchlings and juveniles lived elsewhere, in yet unknown habitats. Taphonomic processes alone would produce a more gradual bias, leaving more specimens of small- and medium-sized A. hofmanni to be found in the Maastrichtian type area.

\section{Acknowledgements}

We wish to thank everyone who has taken the time to ask us questions and thus help us answer our own. For access to the collections and feedback, advice and expertise, we are grateful to Nathalie Bardet, Bert Boekschoten, Daniel Brinkman, Jo Buijs, Sandra Chapman, Annelise Folie, John W.M. Jagt, Walter Joyce, Takuya Konishi, Paul Lambers, Lex Meijer, Johannes Müller, Sjir Renkens, Bert Sliggers, Simon Troelstra, Laura Vietti, John de Vos, Marie-Cécile van de Wiel and Daniela Schwarz-Wings. Of these, Bert Boekschoten and Laura Vietti are thanked again for their helpful reviews after first submission. Eric Mulder's PhD thesis did not only provide an excellent starting point for us, the author himself has also been generous with his help.

\section{References}

Brand, L.R., Goodwin, T.H., Ambrose, P.D. \& Buchheim, P.H., 2000. Taphonomy of turtles in the Middle Eocene Bridger Formation, SW Wyoming. Palaeogeography, Palaeoclimatology, Palaeoecology 162: 171-189.

Brand, L.R., Hussey, M. \& Taylor, J., 2003. Taphonomy of freshwater turtles: decay and disarticulation in controlled experiments. Journal of Taphonomy 1: 233-245.

Camper, $\boldsymbol{P} ., 1786$. Conjectures relative to the petrifactions found in St Peter's Mountain, near Maestricht. Philosophical Transactions of the Royal Society of London 76: 443-456.

Chaloupka, M. \& Zug, G.R., 1997. A polyphasic growth function for the endangered Kemp's ridley sea turtle, Lepidochelys kempii. Fishery Bulletin 95: 849-856.

Dortangs, R.W., Schulp, A.S., Mulder, E.W.A., Jagt, J.W.M., Peeters, H.H.G. \& De Graaf, D.T., 2002. A large new mosasaur from the Upper Cretaceous of The Netherlands. Netherlands Journal of Geosciences 81: 1-8.

Gray, J.E., 1831. Synopsis Reptilium; or short descriptions of the species of reptiles. Synopsis Reptilium, Part 1: Tortoises, Crocodiles and Enaliosaurians. Treuttel, Würtz \& Co. (London): viii + 1-86.

Halliday, T.R. \& Verrell, P.A., 1988. Body size and age in amphibians and reptiles. Journal of Herpetology 22: 253-265.

Herngreen, G.F.W. \& Wong, T.E., 2007. Cretaceous. In: Wong, T.E., Batjes, D.A.J. \& de Jager, J. (eds): Geology of the Netherlands. Royal Netherlands Academy of Arts and Sciences (Amsterdam): 127-150.

Jagt, J.W.M., 1999. Late Cretaceous-Early Palaeogene echinoderms and the K/T boundary in the southeast Netherlands and northeast Belgium - Part 1: Introduction and stratigraphy. Scripta Geologica 116: 1-57.

Kuypers, M.M.M., Jagt, J.W.M., Peeters, H.H.G., De Graaf, D.T., Dortangs, R.W., Deckers, M.J.M., Eysermans, D., Janssen, M.J. \& Arpot, L., 1998. Laatkretaceïsche mosasauriërs uit Luik-Limburg - nieuwe vondsten leiden tot nieuwe inzichten. Publicaties van het Natuurhistorisch Genootschap in Limburg 41: 5-47.

Lutz, P.L., Musick, J.A. \& Wynekenn, J. (eds), 2003. The biology of sea turtles, Vol. II. CRC Marine Biology Series, CRC Press (Boca Raton): 1-472.

Meyer, C.A., 1991. Burial experiments with marine turtle carcasses and their paleoecological significance. Palaios 6: 89-96.

Mulder, E.W.A., 2003. On latest Cretaceous tetrapods from the Maastrichtian type area. Publicaties van het Natuurhistorisch Genootschap in Limburg 44: 1-188.

Perrine, D., 2003. Sea Turtles of the World. Voyageur Press (Stillwater): 1-144.

Reich, K.J., Bjorndal, K.A. \& Bolten, A.B., 2007. The lost years of green turtles: using stable isotopes to study cryptic lifestages. Biology Letters 3: 712-714.

Ubaghs, C., 1883. La mâchoire de la Chelonia Hoffmanni de la Craie supérieure de Maestricht. Annales de la Société géologique de Belgique 10: 25-35

Van der Ham, R.W.J.M., Van Konijnenburg-van Cittert, J.H.A. \& Indeherberge, L., 2007. Seagrass foliage from the Maastrichtian type area (Maastrichtian, Danian, NE Belgium, SE Netherlands). Review of Palaeobotany and Palynology 144: 301-321.

Wyneken, J., 2001. The anatomy of sea turtles. U.S. Department Commerce NOAA Technical Memorandum NMFS SEFSC 470: 1-172.

Zug, G.R., Balazs, G.H. \& Parker, D.M., 2002. Age and growth of Hawaiian green seaturtles (Chelonia mydas): an analysis based on skeletochronology. Fishery Bulletin 100: 117-127. 


\section{Supplementary material}

List of all specimens, including reconstructed carapace length and bone affection types; these data were used to compile Fig. 1.

\section{Legend}

Adult, based on well-defined measurement

Adult, based on measurements of unidentified or very

fragmental bone elements

Unknown, measurements available but not enough

qualitative information

Juvenile

RCL Reconstructed carapace length

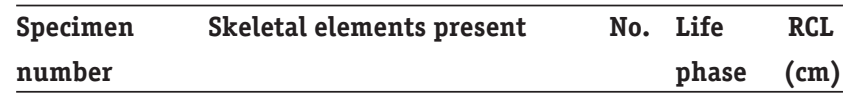

Natuurhistorisch Museum Maastricht (the Netherlands)

\begin{tabular}{|c|c|c|c|c|}
\hline NHMM000001 & Peripherals & 19 & Adult & 143 \\
\hline & Neurals & 9 & & \\
\hline & Costals & 16 & & \\
\hline & Nuchal & 1 & & \\
\hline & Pygal & 1 & & \\
\hline & Suprapygals & 3 & & \\
\hline & Xiphiplastrons & 2 & & \\
\hline & Hypoplastrons & 2 & & \\
\hline & Cranium & 1 & & \\
\hline & Ceratobranchials & 2 & & \\
\hline & Paired Atlas Neural Arch Pieces & 2 & & \\
\hline & Mandible & 1 & & \\
\hline & Cervical Vertebrae & 4 & & \\
\hline & Ribs & 5 & & \\
\hline & Pectoral Girdle & 2 & & \\
\hline & Humeri & 2 & & \\
\hline & Ulna & 1 & & \\
\hline & Radii & 2 & & \\
\hline & Manus & 2 & & \\
\hline & Femur & 1 & & \\
\hline & Tibia/Fibula & 1 & & \\
\hline & Caudal Vertebrae & 2 & & \\
\hline NHMM383 & Costal & 1 & Adult & \\
\hline NHMM881 & Thoracic rib pairs 1 to 6 & 12 & Adult & 129 \\
\hline NHMM001406 & Peripheral & 1 & Adult & 143 \\
\hline NHMM001413 & Peripherals & 2 & Adult & \\
\hline NHMM002056 & Cranium & 1 & Adult & 128 \\
\hline & Mandible & 1 & & \\
\hline NHMM003836 & Costal & 1 & Adult & \\
\hline NHMM003889 & Costal & 1 & Adult & 103 \\
\hline NHMM003890 & Peripheral & 1 & Adult & 164 \\
\hline NHMM003891 & Peripheral & 1 & Adult & \\
\hline NHMM003894 & Peripherals & 2 & Adult & \\
\hline NHMM003901 & Pectoral girdle & 1 & Adult & \\
\hline NHMM003903 & Peripherals & 3 & Adult & 124 \\
\hline NHMM003906 & Sacral vertebrae & 2 & Adult & \\
\hline
\end{tabular}

\begin{tabular}{|c|c|c|c|c|}
\hline & Caudal vertebra & 1 & & \\
\hline & Unidentified bone fragment & 1 & & \\
\hline NHMM003910 & Unidentified vertebra & 1 & Adult & \\
\hline \multirow[t]{4}{*}{ NHMM007978 } & Nuchal & 1 & Adult & 145 \\
\hline & Costals & 2 & & \\
\hline & Neurals & 2 & & \\
\hline & Peripheral & 1 & & \\
\hline NHMM009005 & Cranium & 1 & Adult & 125 \\
\hline \multirow[t]{3}{*}{ NHMM009012 } & Tibia & 1 & Adult & \\
\hline & Fibula & 1 & & \\
\hline & Pes & 1 & & \\
\hline \multirow[t]{17}{*}{ NHMM009016 } & Nuchal & 1 & Adult & 134 \\
\hline & Neurals & 8 & & \\
\hline & Costals & 8 & & \\
\hline & Thoracic vertebrae & 7 & & \\
\hline & Ribs & 7 & & \\
\hline & Suprapygal & 1 & & \\
\hline & Pectoral girdle & 1 & & \\
\hline & Femur & 2 & & \\
\hline & Cranium & 1 & & \\
\hline & Mandible & 1 & & \\
\hline & Ceratobranchial & 1 & & \\
\hline & Humerus & 1 & & \\
\hline & Paired Atlas Neural Arch Piece & 1 & & \\
\hline & Ulna & 1 & & \\
\hline & Radius & 1 & & \\
\hline & Manus & 1 & & \\
\hline & Pygal & 1 & & \\
\hline \multirow[t]{12}{*}{ NHMM009017 } & Manus & 2 & Adult & 149 \\
\hline & Peripherals & 8 & & \\
\hline & Humerus & 1 & & \\
\hline & Radius & 1 & & \\
\hline & Ulna & 1 & & \\
\hline & Hypoplastron & 2 & & \\
\hline & Pygal & 1 & & \\
\hline & Pelvis & 1 & & \\
\hline & Femurs & 2 & & \\
\hline & Tibia & 1 & & \\
\hline & Fibula & 1 & & \\
\hline & Xiphiplastron & 1 & & \\
\hline
\end{tabular}




\begin{tabular}{|c|c|c|c|c|c|c|c|c|c|}
\hline & Hyoplastron & 1 & & & TM5253 & Carapace fragment & 1 & Adult & \\
\hline & Epiplastron & 1 & & & TM7430 & Costal & 1 & Adult & \\
\hline & Entoplastron & 1 & & & TM7431 & Peripheral & 1 & Adult & 155 \\
\hline & Cervical vertebra & 1 & & & TM7432 & Scapula-prescapular process & 1 & Adult & \\
\hline & Caudal vertebrae & 3 & & & TM7434 & Plastron & 1 & Adult & \\
\hline & Unidentified vertebra & 1 & & & TM7451 & Nuchal & 1 & Adult & 140 \\
\hline & Pes & 1 & & & & Neurals & 4 & & \\
\hline & Cranium & 1 & & & & Costals & 8 & & \\
\hline & Mandible & 1 & & & & Peripherals & 2 & & \\
\hline NHMM198350 & Plastron fragment & 1 & Adult & & & Suprapygals & 3 & & \\
\hline NHMM198351 & Peripheral & 1 & Adult & & TM7452 & Nuchal & 1 & Adult & 127 \\
\hline NHMM1991051 & Peripheral & 1 & Adult & 147 & & Peripherals & 4 & & \\
\hline NHMM1992087 & Peripherals & 2 & Adult & & & Costals & 2 & & \\
\hline NHMM1992183 & Costal & 1 & Adult & & TM7453 & Mandible & 1 & Adult & 176 \\
\hline NHMM1995014 & Nuchal & 1 & Adult & & TM7454 & Rib fragments? & 2 & Adult & \\
\hline & Peripherals & 2 & & & TM7455 & Peripherals & 2 & Adult & 149 \\
\hline & Neurals & 9 & & & TM7456 & Peripheral & 1 & Adult & 132 \\
\hline & Costals & 16 & & & TM11208 & Unidentified bone fragment & 1 & Adult & \\
\hline & Suprapygal & 3 & & & TM11221 & Unidentified bone fragment & 1 & Adult & \\
\hline NHMM2010144 & Pygal & 1 & Adult & 176 & TM11240 & Unidentified bone fragment & 1 & Adult & \\
\hline & Peripherals & 2 & & & TM11259 & Pygal & 1 & Adult & \\
\hline NHMM2010145 & Peripheral & 1 & Adult & 142 & TM11263 & Peripheral & 1 & Adult & \\
\hline NHMM2010146 & Peripheral & 1 & Adult & 132 & TM11264 & Neural & 1 & Adult & \\
\hline NHMM2010147 & Peripheral & 1 & Adult & 129 & TM11265 & Costal & 1 & Adult & 131 \\
\hline NHMM2010148 & Peripheral & 1 & Adult & 147 & TM11266 & Peripheral & 1 & Adult & \\
\hline NHMM2010149 & Pygal & 1 & Adult & 107 & TM11267 & Neural & 1 & Adult & 115 \\
\hline NHMM2010150 & Peripheral & 1 & Adult & 121 & TM11268 & Peripheral & 1 & Adult & \\
\hline NHMM2010151 & Unidentified bone fragment & 1 & Adult & & TM11269 & Cranium & 1 & Adult & 102 \\
\hline NHMM2010152 & Unidentified bone fragments & 2 & Adult & & & Cervical vertebrae & & & \\
\hline NHMM2010153 & Unidentified bone fragments & 4 & Adult & & TM11270 & Scapula-prescapular process & 1 & Adult & \\
\hline NHMM2010154 & Unidentified bone fragment & 1 & Unkno & & TM11275 & Unidentified bone fragment & 1 & Unknow? & \\
\hline NHMM2010155 & Unidentified bone fragments & * & Unkno & & TM11277 & Nuchal & 1 & Adult & 110 \\
\hline NHMM2010156 & Neurals & 3 & Adult & 147 & & Peripherals & 2 & & \\
\hline & Costals & 4 & & & & Neurals & 3 & & \\
\hline & Nuchal & 1 & & & & Costals & 6 & & \\
\hline NHMM2010157 & Neurals & 4 & Adult & 131 & TM11279 & Unidentified bone fragment & 1 & Unknow & \\
\hline & Costals & 8 & & & TM11280 & Procoracoid & 1 & Adult & \\
\hline & Suprapygal & 1 & & & TM11281 & Peripheral & 1 & Adult & \\
\hline NHMM2010158 & Pygal & 1 & Adult & & TM11282 & Procoracoid & 1 & Adult & \\
\hline NHMM2010159 & Peripheral & 1 & Adult & & TM11283 & Unidentified bone fragment & 1 & Adult & \\
\hline NHMM2010160 & Mandible & 1 & Adult & & TM11284 & Scapula-prescapular process & 1 & Adult & \\
\hline NHMM2010161 & Femur & 1 & Adult & 150 & TM11285 & Neural & 1 & Adult & \\
\hline NHMM2010162 & Peripherals & $2 ?$ & Adult & & TM11286 & Peripheral & 1 & Adult & 180 \\
\hline NHMM2010163 & Nuchal & 1 & Adult & 155 & TM11288 & Peripherals & 2 & Adult & 144 \\
\hline & Neurals & 2 & & & TM11289 & Nuchal & 1 & Adult & 137 \\
\hline & Costals & 4 & & & & Neurals & 7 & & \\
\hline & Peripherals & 4 & & & & Costals & 13 & & \\
\hline & Pygal & 1 & & & & Suprapygal & 2 & & \\
\hline Teylers Museun & m (Haarlem, the Netherlands) & & & & TM11290 & Mandible & 1 & Adult & 176 \\
\hline TM1353 & Costal & 1 & Adult & 143 & TM11291 & Pelvis & 1 & Adult & \\
\hline TM3949 & Thoracic vertebrae & 3 & Adult & & TM11292 & Costal & 1 & Adult & 144 \\
\hline TM5226 & Carapace fragment & 1 & Unkno & & & Suprapygal & 1 & & \\
\hline TM5239 & Carapace fragment & 1 & Adult & & & Neural & 1 & & \\
\hline
\end{tabular}




\begin{tabular}{|c|c|c|c|c|}
\hline TM11294 & Ulna & 1 & Adult & 201 \\
\hline TM11295 & Scapula-prescapular process & 1 & Adult & \\
\hline TM11296 & Unidentified bone fragment & 1 & Adult & \\
\hline TM11297 & Unidentified bone fragment & 1 & Unknown & \\
\hline TM11298 & Unidentified bone fragment & 1 & Unknown & \\
\hline \multirow[t]{2}{*}{ TM11299 } & Pygal & 1 & Adult & 166 \\
\hline & Peripheral & 1 & & \\
\hline TM11300 & Scapula-prescapular process & 1 & Adult & \\
\hline TM11301 & Scapula-prescapular process & 1 & Unknown & \\
\hline TM11302 & Unidentified bone fragment & 1 & Unknown & \\
\hline TM11303 & Peripheral & 1 & Adult & \\
\hline TM11305 & Scapula-prescapular process & 1 & Unknown & \\
\hline TM11306 & Unidentified carapace element & 1 & Adult & \\
\hline TM11308 & Unidentified bone fragment & 1 & Unknowr & \\
\hline TM11309 & Unidentified bone fragment & 1 & Unknown & \\
\hline TM11323 & Unidentified bone fragment & 1 & Unknown & \\
\hline TM11332 & Peripheral & 1 & Adult & \\
\hline TM11335 & Peripheral & 1 & Adult & \\
\hline TM11336 & Unidentified carapace element & 1 & Adult & \\
\hline TM11337 & Peripheral & 1 & Adult & \\
\hline TM11338 & Nuchal & 1 & Adult & \\
\hline TM11339 & Peripheral & 1 & Adult & 146 \\
\hline \multirow[t]{2}{*}{ TM11352 } & Peripheral & 1 & Adult & 166 \\
\hline & Pygal & 1 & & \\
\hline TM11353 & Peripherals & 2 & Unknowr & \\
\hline \multirow[t]{2}{*}{ TM11354 } & Peripheral & 1 & Unknown & \\
\hline & Unidentified bone fragment & 1 & & \\
\hline TM11355 & Peripherals & 1 & Unknown & \\
\hline \multirow[t]{2}{*}{ TM11357 } & Nuchal & 1 & Adult & 136 \\
\hline & Peripheral & 1 & & \\
\hline \multirow[t]{2}{*}{ TM11359 } & Peripherals & 8 & Adult & 149 \\
\hline & Pygal & 1 & & \\
\hline \multirow[t]{2}{*}{ TM11360 } & Neurals & 3 & Adult & 144 \\
\hline & Costals & 2 & & \\
\hline TM11361 & Mandible & 1 & Adult & \\
\hline TM11366 & Peripheral & 1 & Unknowr & \\
\hline TM11390 & Unidentified bone fragment & 1 & Unknown & \\
\hline TM11394 & Unidentified bone fragment & 1 & Unknown & \\
\hline TM11397 & Unidentified bone fragment & 1 & Unknowr & \\
\hline TM11399 & Cranium fragment & 1 & Adult & \\
\hline TM11404 & Peripheral & 1 & Adult & 151 \\
\hline TM12744 & Unidentified bone fragment & 1 & Unknowr & \\
\hline \multirow[t]{5}{*}{ TM13264 } & Neurals & 3 & Adult & 132 \\
\hline & Costals & 6 & & \\
\hline & Nuchal & 1 & & \\
\hline & Peripheral & 1 & & \\
\hline & Scapula-prescapular process & 1 & & \\
\hline TM13265 & Peripherals & 5 & Adult & 142 \\
\hline TM13266 & Pectoral girdle & 1 & Adult & \\
\hline TM13268 & Pectoral girdle & 1 & Adult & \\
\hline TM13269 & Thoracic vertebrae & 2 & Adult & \\
\hline TM13270 & Thoracic vertebrae & 2 & Adult & \\
\hline TM13271 & Procoracoid & 1 & Adult & \\
\hline
\end{tabular}

\begin{tabular}{lllll} 
TM13272 & Peripherals & 2 & Adult & 195 \\
TM13273 & Peripheral & 1 & Adult & 127 \\
TM13274 & Peripheral & 1 & Adult & \\
TM13275 & Costals & 2 & Adult & 148 \\
& Rib & 1 & & \\
TM13277 & Unidentified bone fragment & 1 & Adult & \\
TM13278 & Nuchal & 1 & Adult \\
TM16793 & Unidentified bone fragments & 5 & Unknown \\
TM16794 & Unidentified bone fragments & a lot & Unknown \\
\hline TM17129 & Cervical vertebra & 1 & Adult \\
\hline TM17130 & Cervical vertebrae & 2 & Adult \\
\hline TM17235 & Unidentified bone fragment & 1 & Unknown \\
\hline TM17237 & Carapace element & 1 & Adult \\
\hline TM17252 & Unidentified appendage fragment 1 & Adult \\
\hline TM21849 & Peripheral & 1 & Unknown \\
\hline TM21850 & Peripheral & 1 & Unknown \\
\hline TM218451 & Carapace fragments & 5 & Unknown \\
TM218452 & Unidentified fragments & 2 & Unknown \\
\hline TM218454 & Appendage fragment & 1 & Adult \\
\hline TM218459 & Unidentified fragments & 2 & Unknown
\end{tabular}

Nederlands Centrum voor Biodiversiteit Naturals

(Leiden, the Netherlands)

\begin{tabular}{|c|c|c|c|c|}
\hline NNM12459 & Nuchal & 1 & Adult & 122 \\
\hline & Neurals & 9 & & \\
\hline & Costals & 16 & & \\
\hline & Suprapygals & 2 & & \\
\hline & Peripherals & 2 & & \\
\hline NNM14000 & Peripheral & 1 & & \\
\hline NNM14016 & Mandible & 1 & & \\
\hline NNM14061 & Mandible & 1 & Adult & 148 \\
\hline \multirow[t]{2}{*}{ NNM14062 } & Cranium & 1 & Adult & 138 \\
\hline & Mandible & 1 & & \\
\hline \multirow[t]{2}{*}{ NNM14063 } & Sacral vertebrae & 2 & Adult & \\
\hline & Caudal vertebra & 1 & & \\
\hline NNM27639 & Peripheral & 1 & Adult & 162 \\
\hline NNM440902 & Unidentified bone element & 1 & Unknown & \\
\hline NNM446890 & Peripheral & 1 & Adult & \\
\hline NNM446891 & Peripheral & 1 & Adult & 122 \\
\hline NNM446892 & Carapace fragment & 1 & Unknown & \\
\hline NNM446894 & Peripheral & 1 & Unknown & \\
\hline NNM446895 & Peripheral & 1 & Adult & 126 \\
\hline NNM446896 & Costal & 1 & Adult & 146 \\
\hline NNM446897 & Unidentified bone element & 1 & Unknown & \\
\hline NNM446898 & Unidentified carapace element & 1 & Unknown & \\
\hline NNM446899 & Nuchal & 1 & Adult & \\
\hline NNM446900 & Peripheral & 1 & Adult & 119 \\
\hline NNM446901 & Nuchal & 1 & Unknown & \\
\hline NNM446903 & Peripheral & 1 & Adult & 118 \\
\hline NNM446904 & Peripherals & 2 & Adult & \\
\hline NNM446905 & Peripheral & 1 & Adult & \\
\hline NNM446906 & Neural & 1 & Adult & \\
\hline NNM446907 & Peripheral & 1 & Adult & 133 \\
\hline NNM446908 & Unidentified bone element & 1 & Unknown & \\
\hline
\end{tabular}




\begin{tabular}{|c|c|c|c|c|c|c|c|c|c|}
\hline \multirow{2}{*}{$\begin{array}{l}\text { NNM446909 } \\
\text { NNM446910 }\end{array}$} & \multirow{2}{*}{$\begin{array}{l}\text { Peripheral } \\
\text { Unidentified bone element }\end{array}$} & \multirow{2}{*}{$\begin{array}{l}1 \\
1\end{array}$} & \multicolumn{2}{|l|}{ Adult } & \multicolumn{2}{|r|}{ Peripherals } & \multicolumn{3}{|l|}{3} \\
\hline & & & \multicolumn{2}{|c|}{ Unknown } & \multirow[t]{4}{*}{ AC8556 } & Nuchal & 1 & \multicolumn{2}{|l|}{ Adult } \\
\hline NNM446911 & Unidentified bone element & 1 & \multicolumn{2}{|c|}{ Unknown } & & Neurals & 3 & & \\
\hline NNM446912 & Unidentified bone element & 1 & \multicolumn{2}{|c|}{ Unknown } & & Costals & 3 & & \\
\hline NNM446913 & Nuchal & 1 & \multicolumn{2}{|c|}{ Unknown } & & Peripherals & 3 & & \\
\hline NNM76729 & Nuchal & 1 & \multicolumn{2}{|c|}{ Unknown } & AC8627 & Pectoral girdle & 1 & Adult & \\
\hline NNM76735 & Pectoral girdle & 1 & \multicolumn{2}{|c|}{ Adult } & $\mathrm{AC}$ uncat 1 & Neural & 1 & Adult & \\
\hline NNM76819 & Peripheral & 1 & Adult & 110 & AC uncat 2 & Neural & 1 & Adult & 104 \\
\hline NNM76820 & Peripheral & 1 & \multicolumn{2}{|l|}{ Adult } & & Costals & 2 & & \\
\hline NNM78240 & Unidentified carapace element & 1 & \multicolumn{2}{|c|}{ Unknown } & & Suprapygals & 2 & & \\
\hline NNM94273 & Peripheral & 1 & \multicolumn{2}{|c|}{ Unknown } & AC uncat 3 & Femur & 1 & Adult & 265 \\
\hline \multirow[t]{2}{*}{ NNM-RR008 } & Peripheral & 1 & Adult & 132 & AC uncat 4 & Unidentified plastron element & 3 & Unknow & \\
\hline & Pygal & 1 & & & $\mathrm{AC}$ uncat 5 & Unidentified bone fragment & 1 & Unknow & \\
\hline Universiteits & useum Utrecht (the Netherlan & & & & AC uncat 6 & Peripherals & $?$ & Unknow & \\
\hline G768.1881 & Neural & 1 & Adult & & AC uncat 7 & Unidentified bone fragments & a lot & Unknow & \\
\hline G788.1883 & Peripheral & 1 & Adult & & Institut Roya & des Sciences Naturelles de Belgi & lue & & \\
\hline G797.1883 & Peripheral & 1 & Adult & & (Brussels, $\mathrm{Be}$ & jium) & & & \\
\hline G811.1883 & Peripheral & 1 & Adult & & 1619 & Hyoplastron & 2 & Adult & 130 \\
\hline G812.1883 & Peripheral & 1 & Unknor & & & Hypoplastron & 1 & & \\
\hline G819.1883 & Peripherals & 2 & Adult & 124 & & Pectoral girdle & 2 & & \\
\hline G824.1883 & Unidentified bone fragment & 1 & Unknov & & & Nuchal & 4 & & \\
\hline G092.1903 & Peripheral & 1 & Adult & & & Peripherals & 12 & & \\
\hline Natuurmuse & n Brabant (Tilburg, the Netherl & nds) & & & 1620 & Sacral vertebrae & 2 & Adult & \\
\hline 041.334 & Neural & 1 & Adult & & & Caudal vertebrae & 5 & & \\
\hline & Carapace or plastron element & 1 & & & 1623 & Mandible & 1 & Adult & 144 \\
\hline & Carapace element & 1 & & & & Mandible & 1 & & \\
\hline 041.242 & Unidentified bone element & 1 & Unknov & & 3106 & Peripherals & $6 ?$ & Adult & \\
\hline 042.222 & Mandible & 1 & Adult & & & Neurals & 4 & & \\
\hline Geologisch M & seum Hofland (Laren, the Neth & tanc & & & & Costals & $3 ?$ & & \\
\hline 1184 & Mandible & 1 & Adult & & & Unidentified carapace fragments & 7 & & \\
\hline 1685 & Peripheral & 1 & Adult & & C44-8 (3175) & Nuchal & 1 & Adult & 123 \\
\hline Peabody Mus & um of Natural History (Yale, Un & es $\mathrm{S}$ & tes) & & & Peripherals & 4 & & \\
\hline YPM9773 & Peripheral & 1 & Adult & 174 & & Costals & 2 & & \\
\hline YPM9774 & Peripheral & 1 & Adult & 163 & & Neurals & 3 & & \\
\hline YPM17826 & Nuchal & 1 & Adult & 111 & & Unidentified bone fragment & 1 & & \\
\hline & Neurals & 9 & & & IG8444 & Peripherals & 2 & Adult & \\
\hline & Costals & 10 & & & IG8612 & Peripherals & 2 & Adult & 148 \\
\hline & Peripherals & 5 & & & & Ulna & 1 & & \\
\hline & Suprapygals & 2 & & & & Unidentified carapace fragment & 1 & & \\
\hline & Pygal & 1 & & & & Suprapygal & 1 & & \\
\hline YPM uncat A & Unidentified bone fragments & 24 & Unknov & & & Pectoral girdle & 1 & & \\
\hline YPM uncat B & Suprapygals & 2 & Adult & & IG8912 & Peripheral & 1 & Adult & \\
\hline YPM uncat C & Costal & 1 & Unknov & & & Neural & 1 & & \\
\hline YPM uncat D & Unidentified bone fragments & 4 & Adult & & & Costal & 1 & & \\
\hline YPM uncat E & Unidentified bone fragments & 6 & Unknov & & IG9694 & Peripherals & 5 & Adult & 127 \\
\hline YPM uncat $F$ & Peripherals & 2 & Adult & 180 & & Unidentified bone fragments & 3 & & \\
\hline Museum fur & aturkunde Berlin (Germany) & & & & & Unidentified vertebra & 1 & & \\
\hline MBR2534 & Mandible & 1 & Adult & & & Pectoral girdle & 1 & & \\
\hline MBR2535 & Peripheral & 1 & Adult & & IG9708 & Pygal & 1 & Adult & 145 \\
\hline Muséum Nat & nal d'Histoire Naturelle Paris ( & ance & & & IRScNB EFR 9 & Mandible & 1 & Adult & 142 \\
\hline AC8324 & Nuchal & 1 & Adult & 124 & $(1623)$ & & & & \\
\hline & Neural & 1 & & & REG1737 & Peripherals & 7 & Adult & 123 \\
\hline & Costals & 2 & & & & Unidentified plastron elements & 12 & & \\
\hline
\end{tabular}




\begin{tabular}{|c|c|c|c|c|}
\hline Unnumbered 1 & Pectoral girdle & 1 & Adult & \\
\hline Unnumbered 3 & Peripheral & 1 & Adult & \\
\hline Unnumbered 4 & Peripherals & 2 & Adult & 121 \\
\hline Unnumbered 5 & Peripherals & 2 & Adult & \\
\hline Unnumbered 6 & Peripheral & 1 & Unknown & \\
\hline Unnumbered 7 & Pectoral girdle & 1 & Unknown & \\
\hline Unnumbered 8 & Peripherals & 2 & Adult & 127 \\
\hline Unnumbered 9 & Unidentified plastron element & 1 & Unknown & \\
\hline Unnumbered 10 & Unidentified bone fragment & 1 & Unknown & \\
\hline Unnumbered 11 & Unidentified vertebra & 1 & Unknown & \\
\hline \multicolumn{5}{|c|}{ Natural History Museum London (United Kingdom) } \\
\hline NHM-R921 & Nuchal & 1 & Adult & \\
\hline NHM11603 & Peripheral & 1 & Unknowr & \\
\hline NHM40173 & Costal & 1 & Adult & \\
\hline NHM42889 & Mandible & 1 & & 163 \\
\hline NHM42890 & Mandible & 1 & & 160 \\
\hline NHM42891 & Mandible & 1 & & 152 \\
\hline NHM42892 & Mandible & 1 & & 153 \\
\hline \multirow[t]{5}{*}{ NHM42893 } & Manus & 1 & & 150 \\
\hline & Humerus & 1 & & \\
\hline & Radius & 1 & & \\
\hline & Ulna & 1 & & \\
\hline & Presum. Hyoid bone & 1 & & \\
\hline \multirow[t]{5}{*}{ NHM42894 } & Pelvis & 1 & Adult & \\
\hline & Thoracic vertebrae & 2 & & \\
\hline & Plastron element & 1 & & \\
\hline & Femur & 1 & & \\
\hline & Sacral vertebra & 1 & & \\
\hline NHM42895 & Pelvis & 1 & Adult & \\
\hline NHM42896 & Neural & 1 & Adult & \\
\hline NHM42897 & Peripheral & 1 & Adult & \\
\hline NHM42898 & Peripheral & 1 & Adult & \\
\hline \multirow[t]{4}{*}{ NHM42899 } & Suprapygals & 2 & Adult & \\
\hline & Pygal & 1 & & \\
\hline & Peripherals & 2 & & \\
\hline & Caudal vertebrae & 5 & & \\
\hline NHM42901 & Plastron element & 1 & Unknown & \\
\hline NHM42902 & Scapula/prescapular process & 1 & Adult & \\
\hline NHM42903 & Scapula/prescapular process & 1 & Adult & \\
\hline NHM42904 & Pectoral girdle & 1 & Adult & \\
\hline NHM42907 & Unidentified bone fragments & 3 & Adult & \\
\hline NHM42910+ & Nuchal & 1 & Adult & \\
\hline \multirow[t]{2}{*}{ NHM42911 } & Costals & 4 & & \\
\hline & Peripherals & 3 & & \\
\hline \multirow[t]{9}{*}{ NHM42912 } & Cervical vertebrae & 6 & & 143 \\
\hline & Scapula & 1 & & \\
\hline & Pectoral girdle & 1 & & \\
\hline & Neurals & 9 & & \\
\hline & Suprapygals & 3 & & \\
\hline & Nuchal & 1 & & \\
\hline & Costals & 11 & & \\
\hline & Peripherals & 8 & & \\
\hline & Pygal & 1 & & \\
\hline
\end{tabular}

\begin{tabular}{|c|c|c|c|}
\hline & Pectoral girdle elements & 2 & \\
\hline \multirow[t]{8}{*}{ NHM42913 } & Pelvis & 1 & 168 \\
\hline & Hyoplastron & 1 & \\
\hline & Plastron element & 1 & \\
\hline & Peripherals & 5 & \\
\hline & Unidentified bone fragments & 4 & \\
\hline & Neurals & 2 & \\
\hline & Mandible & 1 & \\
\hline & Cranium & 1 & \\
\hline \multirow[t]{3}{*}{ NHM42914 } & Pectoral girdle & 1 & Adult \\
\hline & Peripherals & 3 & \\
\hline & Cervical vertebrae & 3 & \\
\hline \multirow[t]{4}{*}{ NHM42915 } & Nuchal & 1 & 119 \\
\hline & Peripherals & 3 & \\
\hline & Neurals & 7 & \\
\hline & Costals & 10 & \\
\hline \multirow[t]{4}{*}{ NHM42916 } & Peripherals & 3 & Adult \\
\hline & Pygal & 1 & \\
\hline & Neurals & 3 & \\
\hline & Costal & 1 & \\
\hline \multirow[t]{3}{*}{ NHM429165a } & Nuchal & 1 & 152 \\
\hline & Peripherals & 4 & \\
\hline & Neural & 1 & \\
\hline NHM42964 & Caudal vertebrae & 6 & Adult \\
\hline \multirow[t]{2}{*}{ NHM42965 } & Nuchal & 1 & 132 \\
\hline & Peripherals & 2 & \\
\hline \multirow[t]{2}{*}{ NHM42967 } & Neurals & 2 & Adult \\
\hline & Dorsal vertebrae & 2 & \\
\hline NHM42968 & Presum. Left hyoplastron & 1 & Adult \\
\hline NHM42970 & Plastron element & 1 & Unknown \\
\hline NHM42971 & Humerus & 1 & Adult \\
\hline NHM42972 & Scapula & 1 & \\
\hline NHM42973 & Femur & 1 & \\
\hline NHM42997 & Cranium & 1 & \\
\hline \multirow[t]{12}{*}{ NHM42999 } & Peripherals & 9 & 144 \\
\hline & Nuchal & 1 & \\
\hline & Pelvis & 1 & \\
\hline & Carapace element & 1 & \\
\hline & Unknown element & 1 & \\
\hline & Rib & 1 & \\
\hline & Neurals & 2 & \\
\hline & Vertebra & 1 & \\
\hline & Mandible & 1 & \\
\hline & Plastron element & 1 & \\
\hline & Unknown elements & $6 ?$ & \\
\hline & Scapula/prescapular process & 1 & Juvenile \\
\hline NHM43467 & Neural & 1 & Adult \\
\hline
\end{tabular}

